\title{
Faktor Penyebab Timbulnya Disparitas dalam Putusan Hakim Terhadap Anak Pelaku Tindak Pidana Pencurian dengan Pemberatan
}

\author{
Sandy Doyoba Alexsander ${ }^{1}$, Yeni Widowaty ${ }^{2}$ \\ 1,2 Fakultas Hukum, Universitas Muhammadiyah Yogyakarta \\ Email : ${ }^{1}$ sandydoyoba03@gmail.com \\ 2 yeniwidowaty@umy.ac.id
}

\section{Info Artikel}

\section{Kata Kunci :}

anak, disparitas, tindak pidana pencurian

Perjalanan Artikel :

Diterima : 24 Juli 2020

Direview : 27 Agustus 2020

Direvisi : 29 Agustus 2020

Dipublikasikan : Agustus 2020

DOI: 10.18196/ijclc.v1i2.9610

\begin{abstract}
Abstrak
Keputusan bahwa anak dapat diberi penjatuhan pidana itu sepenuhnya adalah kebebasan hakim, dalam menjatuhkan pidana hakim harus menyertakan alasan-alasan yang dapat dipertanggungjawabkan atau dalam hal ini dapat disebut dengan pertimbangan hakim. Penelitian ini bertujuan untuk mengetahui pertimbangan hakim dalam menjatuhkan pidana terhadap tindak pidana pencurian dengan pemberatan yang dilakukan oleh anak dan mengetahui faktor-faktor penyebab disparitas pidana dalam penjatuhan putusan hakim terhadap anak sebagai pelaku tindak pidana pencurian dengan pemberatan. Jenis penelitian ini adalah penelitian hukum normatif. Sumber data yang digunakan dalam penelitian ini adalah sumber data sekunder yang diperoleh dari hasil penelitian kepustakaan, yakni putusan pengadilan, buku dan bacaan lain. Sebagai pelengkap, hasil wawancara dalam penelitian ini adalah Taufik Rahman S.H., selaku Hakim Pengadilan Negeri Yogyakarta. Hasil analisis menunjukkan bahwa Hakim dalam menjatuhkan putusan pidana terhadap anak mempertimbangkan latar belakang dilakukan tindak pidana pencurian yang dilakukan oleh anak, hakim juga mempertimbangkan kesimpulan dari laporan hasil Pembimbingan Kemasyarakatan dari BAPAS Yogyakarta, dan hakim juga mempertimbangkan keterangan dari orang tua serta saksi-saksi. Penyebab adanya disparitas pidana dalam putusan hakim terkait dengan tindak pidana pencurian oleh anak dengan pemberatan dikarenakan hakim memiliki kebebasan untuk menentukan berat ringannya pidana, jadi hakim bebas memilih jenis hukuman untuk terdakwa sesuai yang ditentukan oleh Undang-Undang.
\end{abstract}

\section{Pendahuluan}

Saat ini banyak dijumpai anak-anak yang berperilaku menyimpang. Perilaku menyimpang anak ini, jelas tampak kini di tengah-tengah masyarakat. Kenyataan-kenyataan ini menunjukkan bahwa perilaku mereka sudah sangat mengkhawatirkan dan merupakan masalah yang berbahaya. Kenyataan ini disebabkan oleh berbagai faktor antara lain adanya dampak negatif dari arus globalisasi, komunikasi, informasi, kemajuan ilmu pengetahuan dan teknologi, dan perubahan gaya hidup telah membawa perubahan sosial yang mendasar dalam kehidupan masyarakat, terlebih kepada perilaku anak. Kejahatan yang dilakukan anak bentuk dan modusnya pun semakin beragam, mulai dari tindak kejahatan ringan, sampai ke tindak kejahatan berat. $^{1}$

\footnotetext{
1 Puspita, Tiara Arta, "Tinjauan Yuridis terhadap Tidnak Pidana Pencurian yang Dilakukan oleh Anak (Studi Kasus Putusan No. 77/Pid.Sus/2013/PN.Ska dan Putusan No. 258/Pid.Sus/2013/PN.Srg" (Desember, 2017)
} 
Salah satu contoh kejahatan yang sering terjadi di masyarakat yaitu kasus pencurian yang dilakukan oleh oknum-oknum kejahatan yang tidak bertanggungjawab atas perbuatan yang dilakukan, kejahatan pencurian ini terjadi di berbagai kalangan masyarakat umum dan juga dilakukan oleh anak yang masih di bawah umur diakibat pengaruh lingkungan anak yang tidak diberikan arahan yang benar atas perilaku anak tersebut. Sebagian besar anak mempunyai kemampuan dalam mengembangkan dirinya untuk dapat melaksanakan hak dan kewajibannya sebagai warga negara yang bertanggung jawab dan bermanfaat untuk sesama manusia. Kondisi fisik dan mental seorang anak yang masih lemah sering kali memungkinkan dirinya disalahgunakan secara legal atau ilegal, secara langsung atau tidak langsung oleh orang sekelilingnya tanpa dapat berbuat sesuatu.

Pada hakikatnya anak tidak dapat melindungi diri sendiri dari berbagai macam tindakan yang menimbulkan kerugian mental, fisik, sosial, dalam berbagai bidang kehidupan. Perlindungan juga harus diberikan kepada anak yang melakukan perbuatan menyimpang maupun perbuatan yang melanggar hukum, khususnya dalam pelaksanaan peradilan pidana anak yang asing bagi dirinya. Anak perlu mendapat perlindungan dari kesalahan penerapan peraturan perundang-undangan yang diberlakukan terhadap dirinya yang menimbulkan kerugian mental, fisik, dan sosial. Perlindungan anak dalam hal ini disebut perlindungan hukum/yuridis (legal protection). ${ }^{2}$

Kejahatan yang dilakukan oleh orang dewasa, tidak dapat disamakan begitu saja dengan perbuatan anak atau remaja yang biasa dilakukan oleh anak, sebab harus dibedakan sifat dan bentuk perbuatan seorang anak dengan perbuatan orang dewasa. Perlindungan terhadap anak dalam kaitannya anak yang bermasalah dengan hukum, sebagai bagian utama peningkatan kualitas mutu hidup manusia. Penegak hukum yang ditugaskan untuk menyelesaikan perkara pidana anak, perlu kejelian dalam menerapkan jenis sanksi pidana terhadap anak, agar anak tersebut tidak merasa kehilangan haknya sesuai yang diatur dalam Undang-undang No. 11 Tahun 2012 tentang sistem peradilan pidana anak dan Undang-undang No. 23 Tahun 2002 Tentang Perlindungan Anak. ${ }^{3}$

Melalui Direktori Putusan Mahkamah Agung Republik Indonesia ada beberapa putusan kasus pencurian yang terjadi di wilayah Pengadilan Negeri Yogyakarta. Putusan pertama yaitu Putusan Nomor: 14/Pid.B/2011/PN.Yk., pada putusan tersebut terdakwa kasus pencurian adalah satu orang anak yang berusia 16 (enam belas) tahun, telah terbukti secara sah dan meyakinkan bersalah karena melakukan tindak pidana pencurian dalam keadaan yang memberatkan. Pada putusan pertama pengadilan memutuskan menjatuhkan pidana kepada Terdakwa dengan pidana penjara 2 (dua) bulan 15 (lima belas) hari.

Putusan kedua yaitu, Putusan Nomor:10/Pid.SUS-Anak/2015/PN.Yk., pada putusan ini terdakwa kasus pencurian berjumlah tiga orang dengan masing-masing anak berusia 16 (enam belas) tahun, 15 (lima belas) tahun dan 15 (lima belas) tahun. Berbeda dari putusan sebelumnya, pada putusan ini pengadilan memutuskan menjatuhkan pidana kepada terdakwa dengan pidana syarat berupa Pengawasan dengan menempatkan anak di bawah pengawasan Penuntut Umum dan dibimbing oleh Pembimbing Kemasyarakatan selama 4 (empat) bulan.

Berdasarkan uraian latar belakang masalah yang di atas maka, penulis akan mengkaji dan memahami lebih dalam permasalahan yang melatarbelakangi pertimbangan hakim dalam menjatuhkan sanksi kepada pelaku-pelaku tindak pidana pencurian yang dilakukan oleh anak dan menganalisis faktor penyebab mengapa terjadinya disparitas.

\section{Rumusan Masalah}

Pada penelitian ini penulis merumuskan masalah yaitu Apakah faktor-faktor penyebab timbulnya disparitas pidana dalam menjatuhkan putusan hakim terhadap anak sebagai pelaku tindak pidana pencurian dengan pemberatan?

\footnotetext{
2 Maidi Gultom, Perlindungan Hukum terhadap Anak dalam Sistem Peradilan Anak di Indonesia, Bandung, Rafika Aditama, 2008, hlm. 2.

3 Siagian, Pranggi, "Penjatuhan Sanksi Pidana terhadap Anak Pelaku Kejahatan ”, USU Law Journal, III, (Agustus, 2015). hlm. 177.
} 


\section{Metode Penelitian}

Jenis penelitian yang digunakan di dalam penulisan hukum ini adalah penelitian hukum normatif (normative law research). ${ }^{4}$ Sumber data yang digunakan dalam penelitian ini adalah sumber data sekunder, yang terdiri dari putusan pengadilan, buku serta literatur lain yang terkait. ${ }^{5}$ Hasil analisa bahan hukum akan diinterpretasikan menggunakan metode interpretasi (a) sistematis: (b) gramatikal: dan (c) teologis. ${ }^{6}$

\section{Hasil Penelitian dan Analisis}

Pencurian tidak hanya dilakukan oleh orang dewasa melainkan dapat pula dilakukan oleh anak, baik secara sendiri maupun bersama-sama. Sebagaimana ditetapkan pada orang dewasa, pelaku tindak pidana pencurian yang dilakukan oleh anak juga akan dilakukan proses hukum.

Putusan hakim terhadap anak sebagai pelaku tindak pidana pencurian dengan pemberatan diantaranya adalah Putusan pertama yaitu Putusan Nomor: 14/Pid.B/2011/PN.Yk. dan Putusan Nomor: 10/Pid.SUS-Anak/2015/PN.Yk

Terkait dengan penelitian yang dilakukan oleh penulis yang membahas tentang timbulnya disparitas pidana dalam penjatuhan pola putusan hakim terhadap anak, Putusan perkara pidana mengenal adanya suatu kesenjangan dalam penjatuhan pidana yang lebih dikenal dengan disparitas. Disparitas adalah penerapan pidana (disparity of sentencing) yang tidak sama (same Offence) atau terhadap tindak pidana yang sifat berbahayanya dapat diperbandingkan tanpa dasar pemberian yang jelas. Disparitas pidana dipersepsi publik sebagai bukti ketiadaan keadilan (societal justice), secara yuridis formal, kondisi ini tidak dapat dianggap telah melanggar hukum, meskipun demikian sering kali orang melupakan bahwa elemen "keadilan" pada dasarnya harus melekat pada putusan yang diberikan oleh hakim. ${ }^{7}$

Hakim dalam menjatuhkan suatu putusan tidak terikat dengan putusan hakim sebelumnya karena di Indonesia menganut asas Hakim tidak terikat sepenuhnya pada asas The Binding Foce of Precedent, artinya hakim tidak wajib mengikuti putusan hakim sebelumnya dalam perkara sejenis, sehingga dimungkinkan jika kasusnya sama tetapi hasil putusannya berbeda. Disparitas pidana bukanlah sesuatu yang dilarang, karena menurut Muldadi dan Varda Nawawa penerapan pidana yang tidak sama terhadap tindak pidana yang sama dapat diperbandingkan tanpa dasar pembenaran yang jelas. Disparitas masih terjadi dalam putusan pidana yang dilakukan oleh anak terhadap kasus tindak pidana oleh anak dengan pemberatan. ${ }^{8}$ Dalam 2 (dua) kasus perkara anak yang terjadi di dalam waktu yang berbeda sebagai berikut:

1. Perkara Nomor: 14/Pid.B/2011/PN.Yk tentang Tindak Pidana Pencurian yang dilakukan oleh anak.

2. Perkara Nomor: 10/Pid.SUS-Anak/2015/PN.Yk tentang Tindak Pidana Pencurian yang dilakukan oleh anak.

Disparitas terjadi karena pertimbangan yuridis dan pertimbangan non yuridis berbeda pada kedua perkara tersebut. Disparitas pidana juga terjadi karena faktor-faktor pertimbangan hakim yaitu hal-hal yang meringankan dan hal-hal yang memberatkan, selain itu hakim juga mempertimbangkan hasil penelitian kemasyarakatan dalam menjatuhkan sanksi pidananya. Selanjutnya dapat dilihat dari perbandingkan antara kedua perkara pada tabel 1.

\footnotetext{
4 Abdul Kadir Muhammad, 2004, Hukum dan Penelitian Hukum, Cet 1, Bandung, PT Citra Aditya Bakti, hlm. 52.

5 Peter Mahmud Marzuki,2008, Penelitian Hukum, Jakarta, Kencana Prenada Media Group, hlm. 29.

6 Jimly Asshiddiqie,1997, Teori \& Aliran Penafsiran Hukum Tata Negara, Jakarta, Ind. Hill. Co, hlm. 17-18.

7 Moeljatno,1993, Perbuatan Pidana dan Pertanggungjawaban Dalam Hukum Pidana, Bina Aksara, Jakarta, hlm. 75.

8Muldadi dan Barda Nawawa , 1992,Teori-Teori dan Kebiajakan Pidana, Rafika, Bandung, 19hlm. 8.
} 
Tabel 1 Perbandingan Perkara Tindak Pidana Pencurian yang Dilakukan oleh Anak

\begin{tabular}{|c|c|c|}
\hline & 14/Pid.B/2011/PN.Yk & 10/Pid.SUS-Anak/2015/PN.Yk \\
\hline $\begin{array}{l}\text { Latar } \\
\text { belakang } \\
\text { perbuatan } \\
\text { terdakwa }\end{array}$ & 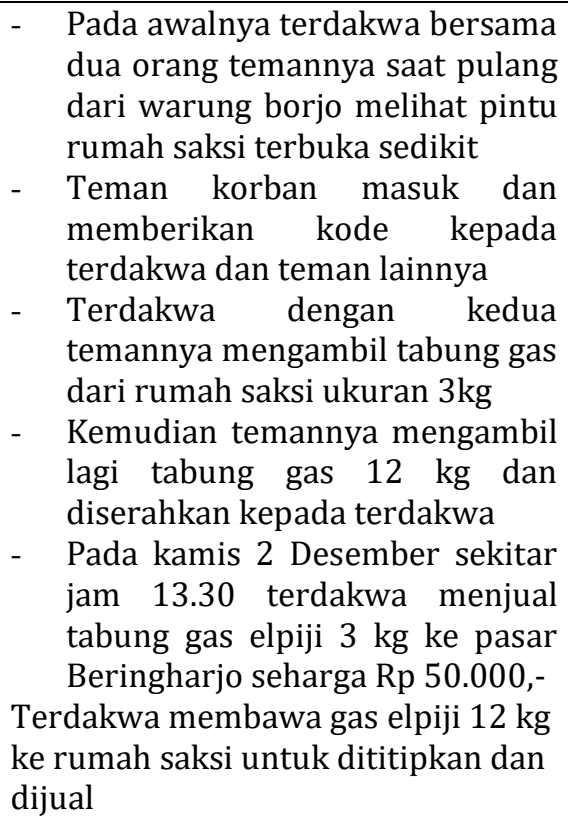 & $\begin{array}{l}\text { - Anak } 1 \text { dan Anak } 3 \text { mendatangi rumah } \\
\text { Anak 3. Kemudian ketiga anak menuju ke } \\
\text { rumah saksi dengan maksud untuk } \\
\text { mengambil HP. } \\
\text { - } \text { Anak } 2 \text { membuka pintu samping dengan } \\
\text { mendorong kemudian mengawasi situasi } \\
\text { di luar rumah } \\
\text { - Anak } 1 \text { dan } 3 \text { masuk ke dalam rumah saksi } \\
\text { dan mengambil } 1 \text { (satu) buah HP Samsung } \\
\text { Galaxy E7 dan } 1 \text { (satu) buah HP Samsung } \\
\text { Tab 3. } \\
\text { Pada Jumat, } 25 \text { September } 2015 \text { pada } \\
\text { pukul } 13.00 \text { Anak } 1 \text { menjual HP Samsung } \\
\text { Tab 3, dan HP Samsung Galaxy E7 oleh } \\
\text { Anak } 3 \text { ditukar dengan HP Asus Zenfon } 2 \\
\text { melalui layanan online. } \\
\text { Uang hasil penjualan HP sebesar Rp 350.000,- } \\
\text { telah habis dipergunakan Anak 1, } 2 \text { dan } 3 \\
\text { untuk makan/jajan dan membeli rokok. }\end{array}$ \\
\hline Umur & 16 tahun 8 bulan & $\begin{array}{l}\text { - } 16 \text { tahun } 8 \text { bulan } \\
\text { - } 15 \text { tahun } 7 \text { bulan } \\
\text { - } \quad 15 \text { tahun }\end{array}$ \\
\hline $\begin{array}{l}\text { Akibat } \\
\text { Perbuatan }\end{array}$ & $\begin{array}{l}\text { Korban menderita kerugian } \mathrm{Rp} \\
340.000 \text {,- }^{-}\end{array}$ & $\begin{array}{l}\text { Korban menderita kerugian sekitar Rp } \\
6.500 .000,-\end{array}$ \\
\hline $\begin{array}{l}\text { Perbuatan } \\
\text { terdakwa } \\
\text { terbukti } \\
\text { secara sah }\end{array}$ & $\begin{array}{l}\text { Terbukti secara sah dan meyakinkan } \\
\text { bersalah melakukan tindak pidana } \\
\text { pencurian dalam keadaan } \\
\text { memberatkan }\end{array}$ & $\begin{array}{l}\text { Terbukti secara sah dan meyakinkan } \\
\text { melakukan tindak pidana pencurian dalam } \\
\text { keadaan memberatkan. }\end{array}$ \\
\hline Status pelaku & Pengamen & $\begin{array}{l}\text { - } \quad \text { Anak 1: Pelajar } \\
\text { - } \quad \text { Anak 2: Pelajar } \\
\text { - } \quad \text { Anak 3: Pelajar }\end{array}$ \\
\hline Dakwaan & $\begin{array}{l}\text { Terdakwa telah didakwa dengan } \\
\text { jenis dakwaan tunggal, yaitu Pasal } \\
363 \text { ayat (1) ke } 3 \text { dan } 4 \text { KUHP. }\end{array}$ & $\begin{array}{l}\text { - Terdakwa telah didakwa dengan jenis } \\
\text { dakwaan tunggal, yaitu Pasal } 363 \text { ayat (1) } \\
\text { ke 3,4 KUHP. }\end{array}$ \\
\hline Barang bukti & $\begin{array}{l}\text { - } 1 \text { (satu) buah tabung gas elpiji } \\
\text { dengan berat } 12 \text { kg warna biru } \\
\text { - } 1 \text { (satu) buah ransel warna } \\
\text { hitam kombinasi biru } \\
\text { bertuliskan Eastpak }\end{array}$ & $\begin{array}{l}\text { - } 1 \text { (satu) unit HP merek Asus tipe Zenfone } 2 \\
\text { warna hitam } \\
\text { - } 1 \text { (satu) HP Evercross A26C warna hitam } \\
\text { - } 1 \text { (satu) buah pengunci rumah warna } \\
\text { coklat panjang } 10 \mathrm{~cm} \text {, lebar } 3 \mathrm{~cm} \text {, kondisi } \\
\text { bengkok }\end{array}$ \\
\hline Vonis hakim & $\begin{array}{l}\text { Menjatuhkan pidana kepada } \\
\text { terdakwa dengan pidana penjara } \\
\text { selama } 2 \text { (dua) bulan dan } 15 \text { (lima } \\
\text { belas) hari }\end{array}$ & $\begin{array}{l}\text { Menjatuhkan pidana terhadap Anak } 1 \text {, Anak } 2 \text {, } \\
\text { dan Anak } 3 \text { dengan pidana syarat berupa } \\
\text { pengawasan dengan menempatkan anak di } \\
\text { bawah pengawasan Penuntut Umum dan } \\
\text { dibimbing oleh Pembimbing Kemasyarakatan } \\
\text { selama } 4 \text { (empat) bulan }\end{array}$ \\
\hline
\end{tabular}

Berdasarkan pada tabel di atas dapat dilihat bahwa kedua perkara tersebut terjadi perbedaan pada penjatuhan pidana oleh hakim dengan kasus yang sama. Kedua perkara tersebut memiliki jenis dakwaan yang sama yaitu dengan dakwaan tunggal dan isi dari dakwaan tersebut juga sama, yaitu sama-sama melanggar Pasal 363 ayat (1) ke-3 dan ke-4. Dalam kedua perkara 
tersebut terdakwa sama-sama telah terbukti secara sah dan meyakinkan melakukan tindak pidana pencurian dengan pemberatan. Usia dari masing-masing terdakwa juga relatif sama yaitu 15 tahun dan 16 tahun, dimana sesuai Pasal 1 ayat (3) Undang-Undang Nomor 11 Tahun 2012 tentang Sistem Peradilan Anak bahwa terdakwa anak masih dikategorikan di bawah umur, yakni Anak belum genap berusia 18 (delapan belas) tahun. Sesuai dengan Pasal 69 Undang-undang Nomor 11 tahun 2012 Tentang Sistem Peradilan Pidana Anak, anak yang belum genap berusia 18 (delapan belas) tahun dapat dikenakan sanksi pidana. Jika anak masih berusia 14 (empat belas) tahun ke bawah hanya dikenakan hukuman tindakan. Ditegaskan dalam Pasal 81 ayat (3) Undang-undang Sistem Peradilan Pidana Anak bahwa Pidana penjara yang dapat dikenakan kepada Anak paling lama $1 / 2$ (satu per dua) tahun dari tuntutan orang dewasa.

\section{Faktor-Faktor Penyebab Timbulnya Disparitas Pidana dalam Penjatuhan Putusan Hakim terhadap Anak sebagai Pelaku Tindak Pidana Pencurian dengan Pemberatan}

Mengingat hal yang mendasar dalam Undang-undang Sistem Peradilan Pidana Anak guna menangani yang berhadapan dengan hukum adalah dengan menggunakan pendekatan melalui keadilan restoratif dan diversi, maka yang dimaksud adalah untuk menghindari dan menjauhkan anak di proses peradilan, sehingga dapat menghindari stigmatisasi terhadap anak yang berhadapan dengan hukum dan diharapkan anak dapat kembali ke dalam lingkungan yang wajar.

Sebagaimana dalam Undang-undang Sistem Peradilan Pidana Anak untuk menangani kasus anak yang berhadapan dengan hukum wajib mengutamakan pendekatan keadilan restoratif, dan diupayakan melalui pendekatan diversi. Sejalan dengan itu putusan Pengadilan Negeri Yogyakarta Nomor: 14/Pid.B/2011/PN.Yk dan Nomor: 10/Pid.SUS-Anak/2015/PN.Yk bahwa pendekatan diversi sudah diterapkan dalam proses penyidikan, akan tetapi pendekatan tersebut belum berhasil dikarenakan tidak adanya kesepakatan dari pihak korban.

Hasil dari vonis hakim terhadap terdakwa pada masing-masing putusan yaitu: untuk perkara Nomor: 14/Pid.B/2011/PN.Yk terdakwa dijatuhi hukuman dengan pidana penjara selama 2 (dua) bulan dan 15 (lima belas) hari. Sedangkan untuk perkara Nomor: 10/Pid.SUSAnak/2015/PN.Yk dijatuhkan pidana terhadap Anak kesatu, Anak kedua, dan Anak ketiga dengan pidana syarat berupa pengawasan dengan menempatkan anak di bawah pengawasan Penuntut Umum dan dibimbing oleh Pembimbing Kemasyarakatan selama 4 (empat) bulan.

Faktor-faktor terjadinya disparitas pidana dalam kedua putusan hakim mengenai tindak pidana pencurian oleh anak dengan pemberatan yaitu: pada perkara Nomor: 14/Pid.B/2011/PN.Yk hanya mempertimbangkan khususnya pasal 363 ayat (1) ke 3 dan 4 KUHP. Ini merupakan Pasal umum yang oleh didakwakan oleh Penuntut Umum kepada tersangka, sehingga tidak mempertimbangkan mengenai Undang-undang Nomor 11 Tahun 2012 tentang Sistem Peradilan Pidana Anak, yang di putusan Nomor: 10/Pid.SUS-Anak/2015/PN.Yk secara khusus dipertimbangkan. Sedangkan pada perkara Nomor: 10/Pid.SUS-Anak/2015/PN.Yk hakim memperhatikan khususnya Pasal 363 ayat (2) KUHPidana dan Undang-undang Nomor 11 Tahun 2012 tentang Sistem Peradilan Pidana Anak.

Menurut Undang-undang Nomor 11 Tahun 2012 tentang Sistem Peradilan Pidana Anak, seorang pelaku tindak pidana anak dapat dikenakan dua jenis sanksi, yaitu tindakan bagi pelaku tindak pidana yang berumur di bawah 14 (empat belas) tahun (Pasal 69 ayat (2) Undang-undang Nomor 11 Tahun 2012 tentang Sistem Peradilan Pidana Anak) dan Pidana, bagi pelaku tindak pidana yang berumur 15 (lima belas) tahun ke atas. Sanksi yang dapat dikenakan kepada anak menurut Pasal 82 Undang-undang Nomor 11 Tahun 2012 tentang Sistem Peradilan Pidana Anak meliputi: pengembalian kepada orang tua/wali, penyerahan kepada seseorang, perawatan di rumah sakit jiwa, perawatan di LPKS, kewajiban mengikuti pendidikan formal dan atau pelatihan yang diadakan oleh pemerintah atau badan swasta, pencabutan surat izin mengemudi dan atau perbaikan akibat tindak Pidana. Atau untuk tindak pidana yang terjadi pada anak berumur 15 (lima belas) tahun ke atas juga bisa mendapatkan Sanksi Pidana (Pasal 71 Undang-undang Nomor 11 Tahun 2012 tentang Sistem Peradilan Pidana Anak), dimana Pidana Pokok terdiri dari: 
a) Pidana peringatan,

b) dengan syarat, yang terdiri atas: pembinaan di luar lembaga, pelayanan masyarakat, atau pengawasan

c) Pelatihan kerja

d) Pembinaan dalam lembaga

e) Penjara

Hasil pengamatan yang diperoleh berdasarkan Undang-undang dan pertimbangan hakim, bahwa Hakim dalam menjatuhkan vonis hukuman baik untuk perkara Nomor: 14/Pid.B/2011/PN.Yk dan Nomor: 10/Pid.SUS-Anak/2015/PN.Yk sudah mempertimbangkan Undang-undang yang terkait. Meski begitu pada Undang-undang Nomor 11 Tahun 2012 tentang Sistem Peradilan Pidana Anak pada perkara Nomor: 14/Pid.B/2011/PN.Yk belum dipertimbangkan, karena Undang-undang Nomor 11 Tahun 2012 tentang Sistem Peradilan Pidana Anak baru ada pada tahun 2012, sedangkan perkara tersebut terjadi pada tahun 2010. Untuk itu pada peraka Nomor: 14/Pid.B/2011/PN.Yk hakim hanya mempertimbangkan Pasal 363 ayat (1) ke 3 dan 4 KUHP. Meski demikian dilihat dari vonis yang diberikan kepada terdakwa sudah sesuai dengan Undang-undang yang berlaku saat itu.

Disparitas pidana juga dilatar belakangi oleh adanya ketentuan dalam Undang-undang Kekuasaan Kehakiman yang memberi kebebasan bagi hakim dalam menjatuhkan sanksi pidana terhadap pelaku yang telah ditentukan oleh Undang-undang. Selain itu, penilaian masing-masing hakim terhadap fakta hukum yang diperoleh dari persidangan juga menjadi faktor timbulnya disparitas pidana. Misalnya dalam perkara Nomor: 14/Pid.B/2011/PN.Yk hakim memperhatikan hasil Litmas atas diri anak yang telah dilakukan oleh BAPAS Yogyakarta yang menyarankan agar terdakwa tetap dijatuhi pidana sesuai dengan masa penahanannya, selain itu juga muncul fakta bahwa terdakwa sedang tidak menjalankan sekolah formal dan statusnya adalah sebagai pengamen. Sedangkan pada perkara Nomor: 10/Pid.SUS-Anak/2015/PN.Yk Pembimbing Kemasyarakatan pada BAPAS Yogyakarta memberikan rekomendasi anak sedang mengikuti kegiatan pembelajaran di sekolah formal.

\section{Simpulan dan Saran}

\section{Simpulan}

Pertimbangan hakim dalam menjatuhkan sanksi pidana bagi anak sebagai pelaku tindak pidana pencurian dengan pemberatan dalam perkara di Pengadilan Negeri Yogyakarta nomor perkara 14/Pid.B/2011/PN.Yk dan 10/Pid.SUS-Anak/2015/PN.Yk dengan mempertimbangkan latar belakang tindak pidana pencurian yang dilakukan oleh anak, laporan dari hasil pembimbingan kemasyarakatan BAPAS Yogyakarta, mempertimbangkan keterangan orang tua dan saksi-saksi, dan mempertimbangkan faktor yang meringankan maupun memberatkan bagi terdakwa. Adapun faktor yang menyebabkan terjadinya disparitas dalam kedua putusan tersebut karena belum berlakunya UU SPPA dalam perkara Nomor 14/Pid.B/2011/PN.Yk dan hakim memang memiliki kebebasan untuk menentukan berat ringannya pidana sebagaimana yang ditetapkan dalam undang-undang.

\section{Saran}

Berdasarkan kesimpulan di atas, sebaiknya hakim dalam menjatuhkan sanksi pidana terhadap anak harus memiliki tujuan untuk mendidik anak agar di kemudian hari anak tidak mengulangi perbuatan pidana lagi, dan hakim juga harus lebih memikirkan masa depan yang lebih baik bagi anak. Kemudian apabila terjadi perbedaan sanksi pidana dalam kasus yang sama disarankan kepada hakim agar perbedaan sanksi pidana tersebut tidak terlalu jauh perbedaannya. 


\section{DAFTAR PUSTAKA}

\section{Buku}

Maidi Gultom, 2008, Perlindungan Hukum Terhadap Anak dalam Sistem Peradilan Anak di Indonesia, Bandung, Rafika Aditama

Moeljatno, 1993, Perbuatan Pidana dan Pertanggungjawaban Dalam Hukum Pidana, Jakarta, Bina Aksara.

Muldadi dan Barda Nawawa, 1992, Teori-Teori dan Kebiajakan Pidana, Alumni, Cetakan Ke-2, Bandung Rafika.

Peter Mahmud Marzuki, 2008, Penelitian Hukum, Jakarta, Kencana Prenada Media Group.

\section{Jurnal}

Mulyadi, Mahmud, 2008, Perlindungan Terhadap Anak yang Berkonflik Dengan Hukum: Upaya Menggeser Keadilan Retributif Menuju keadilan restoratif, Jurnal Equity, XIII

Puspita, Tiara Arta, 2017, Tinjauan Yuridis terhadap Tindak Pidana Pencurian yang Dilakukan oleh Anak (Studi Kasus Putusan No. 77/Pid.Sus/2013/PN.Ska dan Putusan No. 258/Pid.Sus/2013/PN.Srg, Jurnal Hukum Universitas Slamet Riyadi, Vol. 1, No. 1.

Siagian, Pranggi, 2015, Penjatuhan Sanksi Pidana terhadap Anak Pelaku Kejahatan, USU Law Journal, III.

\section{Perundang-undangan}

Undang-Undang Dasar Negara Republik Indonesia 1945

Kitab Undang-Undang Hukum Pidana

Kitab Undang-Undang Hukum Perdata

Undang-undang Nomor 23 Tahun 2002 Tentang Perlindungan Anak

Undang-undang Nomor 39 Tahun 1999 Tentang Hak Asasi Manusia

Undang-undang Nomor 1 Tahun 1974 Tentang Perkawinan

Undang-undang Nomor 25 tahun 1997 Tentang Ketenagakerjaan

Undang-Undang Nomor 11 Tahun 2012 Tentang Sistem Peradilan Pidana Anak 